\title{
EFFECT OF PROJECT COST AND TIME MONITORING ON PROGRESS OF CONSTRUCTION PROJCT
}

\author{
Shreyash Raut ${ }^{1}$, S S Pimplikar ${ }^{2}$, Karan Sawant ${ }^{3}$ \\ ${ }^{1}$ Research Graduate ME Civil Construction \& Management, Civil Engineering, Maharashtra Institute Of \\ Technology,Pune,Maharashtra,India,srraut16@gmail.com \\ ${ }^{2}$ Professor \& Head Of Department, Civil Engineering, Maharashtra Institute Of Technology, Pune, Maharashtra, \\ India, sunil_pimplikar@rediffmail.com \\ ${ }^{3}$ ME Civil Construction \& Management, Civil Engineering, Maharashtra Institute Of Technology, Pune, \\ Maharashtra, India
}

\begin{abstract}
During the construction phase it is the prime responsibility of project managers to monitor cost and avoid any overruns to maintain the cost baseline. Project monitoring is an ongoing process and its importance cannot be undermined during the project life cycle. It can be monitored by using traditional approach of direct reporting of actual cost against budget. However, the comparison of budget versus actual spending does not indicate the worth of the work which is completed at any given time. This approach does not portray the true cost performance of the project. In general Construction cost control consists of simply monitoring actual performance against cost estimates and identifying variances. It has been usually seen there is a lack of systematic and automated evaluation and monitoring system in construction project. Due to these limitations, this paper discusses traditional project monitoring practices in construction industry and proposes some guideline for improving cost management in fast, complex and uncertain construction projects. Such guideline involves the integrated application of Average Index formula and S-curves. This study discusses the result of questionairre survey conducted on various construction sectors to show how cost is compare as prime constraint in real estate sector.
\end{abstract}

Index Terms: Cost management, project monitoring, Average index formula.

\section{INTRODUCTION}

Effective cost monitoring and controlling has received much attention in the construction industry due to excessive cost escalation and woefull profit margin of some contractors. The life cycle of construction projects comprise of different phases including planning initiation, procurement contract award and contract management phase. [6]. Government construction client panel bench-marking study carried out in 1999 in UK shows that three quarter of the 66 projects studies on the central government construction project exceeded $50 \%$ of their contract price [4]. It is usually seen in construction sector cost and time management is given more importance.

\subsection{Monitoring in construction}

Project monitoring is the process where the construction resources of project is managed through the best methods and techniques so that the client does not suffer the losses when carrying out the project activities. According to Barnes, the main problem that accounts for poor cost management by traditional methods is flaws in cost estimates and cost control process, inadequate information modeling, and lack of integration of cost management and production management system[3].Project monitoring is considered to be a managerial process, which aims to generate information to support decision-making and to stimulate cost reduction, value improvement and continuous improvement in the organization. Cost monitoring is understood as being composed of two main processes: cost estimating processes and cost planning and control processes. The objective of cost estimating process is to estimate the cost of products and processes involved in production. This requires a thorough understanding of the design, contracts and production in order to properly model the consumption of resources by transformation and flow (non-value adding) activities. This process starts usually by producing budget normally at early project phase. After cost have been estimated, the financial performance must be planned and controlled during the production phase by means of a cycle composed by two sub-processes, cost planning and cost control. Cost planning involves refining the initial cost estimate and generating a project cash flow, based on additional information that is generated along the project .The aim of the cost control sub-process is to monitor actual cost performance and identify improvement opportunities, which must be dealt by corrective actions. According to Zubair Ahmed Memon, An integrated simulation model ,named DCM (Digitalizing the Construction Monitoring) is developed to integrate digital images of construction scene with AutoCAD drawings and it resolves the existing project progress reporting problems. The DCM model improve the decision-making and productivity of construction activity[8] 


\section{AIMS \& OBJECTIVES}

In construction almost all client are interested in obtaining fully functional facilities completed in time, cost and quality. A builder who is able to construct within the estimated time and budget, to right standard and scope is an excellent builder. The questionairre survey form was designed to verify the time, cost and quality constraints. The main aim of the paper is to reflect how cost is been consider as a prime constraint in real estate sector. The focus of questionairre was to get information about monitoring from four field of construction industry such as Road \& highways, Bridges \& Stadium, Real estate and Oil \& gas. It also shows the relation between project control and monitoring with progress of project.

\section{QUATIONAIRRE SURVEY}

A questionairre survey form was designed to collect data. It consists of private and public sector projects such as Roads \& Highway, Bridges \& stadiums, Real estate and oil \& gas. Data had been collected by face to face interview \& by getting draft of questionairre filled through e-mails. Following table shows the number of respondent from each sector.

Table -1: Total no. of respondent

\begin{tabular}{|l|c|}
\hline \multicolumn{1}{|c|}{ Sector } & No of respondent \\
\hline Roads \& Highway & 09 \\
\hline Bridges \& Stadiums & 08 \\
\hline Real Estate & 09 \\
\hline Oil \& Gas & 10 \\
\hline
\end{tabular}

The data was collected by using measurement on Likert scale. Five scale rating was used to determine the influence. The analysis was based on the qualitative measurement or ranking system. Rating for the questionairre for each parameter has been given separately as below. Average Index Formula as given by Abd.Majid[1] has been used for analysis-

$$
\text { Average Index }(\mathrm{A} I)=\frac{\sum\left(\beta^{*} \mathrm{n}\right)}{\mathrm{N}}
$$

' $n$ ' is the frequency of the respondents

' $\mathrm{N}$ ' is the total number of respondents

\subsection{To determine rating of time, cost \& quality for each sector}

Weightage given is as follows-
Table -2: Weightage table to determine rating of time, cost $\&$ quality

\begin{tabular}{|c|c|}
\hline Ranking by Respondent & $\begin{array}{c}\text { Corresponding } \\
\text { weightage }(\beta)\end{array}$ \\
\hline 1 & 3 \\
\hline 2 & 2 \\
\hline 3 & 1 \\
\hline
\end{tabular}

With the rating scale as below,

Less importance $(1.00<$ Average Index $<1.5)$

Average Importance $(1.5<$ Average Index $<2.5)$

High Importance $(2.5<$ Average Index $<3.5)$

Level of importance can be found by the formula,

Level of Importance $(\%)=\frac{\text { Rating of parameter }}{6} * 100$

\subsection{Data collection for each sector}

Table -3: Data collection of Roads \& Highways sector

\begin{tabular}{|c|c|c|c|c|c|c|c|c|c|c|c|}
\hline \multirow{2}{*}{ Desc } & \multicolumn{10}{|c|}{ AI } & $\%$ \\
\cline { 2 - 11 } & 1 & 2 & 3 & 4 & 5 & 6 & 7 & 8 & 9 & & \\
\hline Time & 1 & 2 & 2 & 1 & 2 & 1 & 3 & 2 & 1 & 2.3 & 38.8 \\
\hline Cost & 2 & 1 & 3 & 2 & 1 & 3 & 2 & 1 & 3 & 2.0 & 33.3 \\
\hline Quality & 3 & 3 & 1 & 3 & 3 & 2 & 1 & 3 & 2 & 1.6 & 27.7 \\
\hline
\end{tabular}

Table -4: Data collection of Bridges \& Stadiums sector

\begin{tabular}{|c|c|c|c|c|c|c|c|c|c|c|}
\hline \multirow{2}{*}{ Desc } & \multicolumn{7}{|c|}{ AI of Respondent } & $\%$ \\
\cline { 2 - 11 } & 1 & 2 & 3 & 4 & 5 & 6 & 7 & 8 & & \\
\hline Time & 1 & 1 & 2 & 1 & 2 & 1 & 2 & 2 & 2.5 & 41.6 \\
\hline Cost & 3 & 3 & 1 & 2 & 3 & 3 & 3 & 3 & 1.3 & 22.9 \\
\hline Quality & 2 & 2 & 3 & 3 & 1 & 2 & 1 & 1 & 2.1 & 35.4 \\
\hline
\end{tabular}

Table -5: Data collection of Real estate sector

\begin{tabular}{|c|c|c|c|c|c|c|c|c|c|c|c|}
\hline \multirow{2}{*}{ Desc } & \multicolumn{10}{|c|}{ AI } & $\%$ \\
\cline { 2 - 12 } & 1 & 2 & 3 & 4 & 5 & 6 & 7 & 8 & 9 & & \\
\hline Time & 2 & 1 & 3 & 2 & 1 & 3 & 3 & 1 & 3 & 1.8 & 31.4 \\
\hline Cost & 1 & 2 & 2 & 1 & 2 & 1 & 2 & 2 & 1 & 2.4 & 40.7 \\
\hline Quality & 3 & 3 & 1 & 3 & 3 & 2 & 1 & 3 & 2 & 1.6 & 27.7 \\
\hline
\end{tabular}

Table -6: Data collection of oil \& gas sector

\begin{tabular}{|c|c|c|c|c|c|c|c|c|c|c|c|c|}
\hline \multirow{2}{*}{ Desc } & \multicolumn{10}{|c|}{ AI } & $\%$ \\
\cline { 2 - 12 } & 1 & 2 & 3 & 4 & 5 & 6 & 7 & 8 & 9 & 0 & & \\
\hline Time & 2 & 1 & 3 & 2 & 1 & 3 & 2 & 1 & 3 & 2 & 2.0 & 33.3 \\
\hline Cost & 3 & 3 & 1 & 3 & 3 & 2 & 1 & 3 & 2 & 3 & 1.6 & 26.6 \\
\hline Quality & 1 & 2 & 2 & 1 & 2 & 1 & 3 & 2 & 1 & 1 & 2.4 & 40.0 \\
\hline
\end{tabular}


A graph plotted from the calculation \& results shown in 3.2, summarizes the level of importance for monitoring time, cost and quality in different sector of construction industry-

Table -7: Summary table

\begin{tabular}{|l|l|l|l|}
\hline Sectors & Time (\%) & Cost (\%) & Quality(\%) \\
\hline $\begin{array}{l}\text { Roads \& } \\
\text { Highways }\end{array}$ & 38.88 & 33.33 & 27.77 \\
\hline $\begin{array}{l}\text { Bridges \& } \\
\text { Stadiums }\end{array}$ & 41.66 & 22.92 & 35.42 \\
\hline Real estate & 31.48 & 40.74 & 27.77 \\
\hline Oil \& Gas & 33.33 & 26.67 & 40 \\
\hline
\end{tabular}

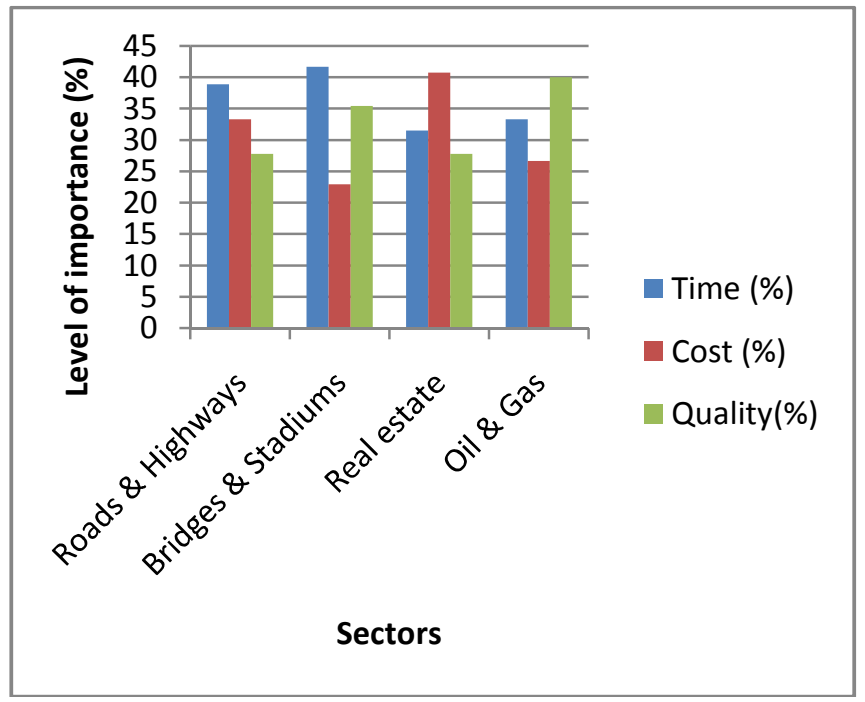

Chart -1: Monitoring status for cost, time \& quality in different sectors.

Key finding from above graph-

- It is seen that in roads \& highways sector more importance is given for time as compare to cost and quality for monitoring.

- In case of bridges and stadium, time and quality are more important to complete the project within time frame and of desired quality.

- In Real estate sector as it is mostly commercial in nature, more importance is given for cost monitoring.

- Oil \& gas which is only sector where quality has been given more importance as compared to other sectors. Importance has been given for time also for monitoring purpose.

\section{PROJECT MONITORING \& CONTROLLING}

As project grows in size and complexity, the ability to plan, monitor and control the project has become a key project management function. Like any other business, builders, contractors and developers have to plan and organize their day to day activities in order to manage effectively. The task of project monitoring and control is to give a fair indication of the existence and the extent of problems associated with a project. For monitoring and controlling purposes, the original detailed cost estimate is typically converted to a project budget, and the project budget is used subsequently as a guide for management. According to Al-jibouri, within construction, divergences from the original plan will occur ; therefore project should have a control cycle as follows with the aim of completing project within acceptable time and budget[2].Monitoring and control cycle consists-

- Make a plan

- Implement the plan

- Monitor the actual output and record it.

- $\quad$ Report the actual, the planned parameters and their variations.

- Take corrective action on the variation
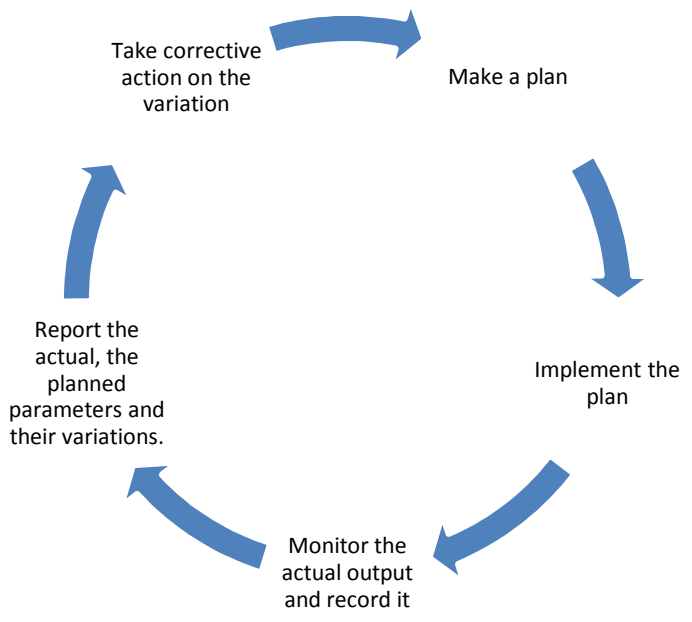

Fig -1: Monitoring and control cycle

A project cost can be usually classified into direct, indirect and overhead cost. During the budgeting process, all these costs are summed up to develop a cost baseline A cost baseline is defined as cumulative time-phased budget that will be used to measure and monitor the current and future project cost performance[7].It is graphically represented in the form of S-curve and it is an important cost monitoring tool. It allows the user to see the project cash flow over the period of time and make it possible to forecast the trends of future spending. The purpose of project monitoring and controlling is to allow the project to be completed within the approved budget and time.

\subsection{Relation between project control, monitoring and project progress}

An effective project performance of the project control cannot be achieved only by monitoring the actual physical progress with the planned progress and actual spending with the budgeted values. Harris and McCaffer describe monitoring as the act of checking actual progress and actual resource usage against planned and the act of taking 
decision to alter the likely future outcome and bring the project back on the planned schedule is control [5].The data is collected from the questionairres by respondent at several stages of project showing the weightage for project control and project progress. The questionairre was prepared in order to determine whether project progress control and monitoring affects the progress of project. Therefore a close end questionairre was designed for this study; to identify the current practice. A typical S-curve was used. Weightage given to find out the relation between project control \& monitoring and project progress were as follow,

Table -8: Weightage table to find relation between project control \& monitoring and project progress

\begin{tabular}{|c|c|c|}
\hline $\begin{array}{c}\text { Ranking given by } \\
\text { respondent }\end{array}$ & $\begin{array}{c}\text { Weightage Range } \\
(\%)\end{array}$ & $\begin{array}{c}\text { Average } \\
\text { Weightage }(\%)\end{array}$ \\
\hline 1 & 75 to 100 & 87.5 \\
\hline 2 & 50 to 75 & 62.5 \\
\hline 3 & 25 to 50 & 37.5 \\
\hline 4 & 0 to 25 & 12.5 \\
\hline
\end{tabular}

Weightage given by the respondent from various constructions sector (Roads \& highways, Bridges \& stadiums, Real estate and Oil \& gas) for the progress monitoring and control into stages of project i.e. Award of project, start of project, middle of project and closure of project. Following were the data collection and calculation showing average rating given to each parameter in all four field of construction industry-

Table -9: Data collection for project stage in different sectors

\begin{tabular}{|c|c|c|c|c|c|}
\hline \multirow{2}{*}{$\begin{array}{l}\text { Project } \\
\text { stage }\end{array}$} & \multicolumn{4}{|c|}{ Sector } & \multirow[b]{2}{*}{$\begin{array}{c}\text { Average } \\
\text { Index }\end{array}$} \\
\hline & $\begin{array}{c}\text { Roads \& } \\
\text { Highways }\end{array}$ & $\begin{array}{c}\text { Bridges } \\
\& \\
\text { Stadiums }\end{array}$ & $\begin{array}{c}\text { Real } \\
\text { Estate }\end{array}$ & $\begin{array}{c}\text { Oil } \\
\& \\
\text { Gas }\end{array}$ & \\
\hline Award & 1 & 1 & 2 & 1 & $81.25 \%$ \\
\hline Start & 2 & 2 & 1 & 2 & $68.75 \%$ \\
\hline Middle & 4 & 3 & 3 & 3 & $31.25 \%$ \\
\hline Closure & 3 & 4 & 4 & 4 & $18.75 \%$ \\
\hline
\end{tabular}

Assuming that project progress at Award stage is 5\%, at Start stage is $30 \%$, at Middle stage is $60 \%$ and at closure stage is $100 \%$.A S-curve is been plotted to show the relation between project control \& monitoring and project progress as shown below in chart2.
Table -10: Summary table

\begin{tabular}{|c|c|c|}
\hline Project Stage & $\begin{array}{l}\text { Project } \\
\text { Monitoring \& } \\
\text { control }\end{array}$ & Project Progress \\
\hline Award & $81.25 \%$ & $5 \%$ \\
\hline Start & $68.75 \%$ & $30 \%$ \\
\hline Middle & $31.25 \%$ & $60 \%$ \\
\hline Closure & $18.75 \%$ & $100 \%$ \\
\hline
\end{tabular}

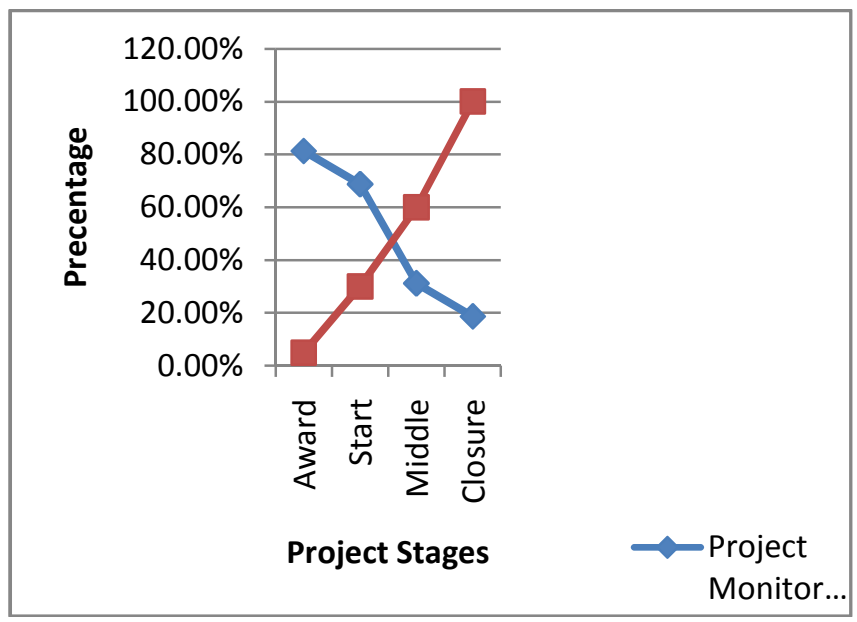

Chart -2: S-curve showing relation between project control and project progress.

From the above plotted graph some findings interpreted were,

- It is seen that overall project monitoring and control process goes on decreasing as project progresses.

- $\quad$ Project monitoring \& control process is maximum from award stage to start stage of project but it is less from middle stage to closure stage of project.

- For any project start stage to middle stage is very important hence it is necessary to monitor and control the project but from above plotted graph it is seen that monitoring and controlling process goes decreasing which can be a major cause for delays.

\section{CONCLUSIONS}

This research has identified that the weightage given for time, cost and quality in different sector is not the same. The main finding can be said that in real estate more weightage is given for cost rather than time and quality. Successful implementation of average index can result in the relation between project monitoring and progress of project .Graph clearly shows that project monitoring decreases as the project progresses. Thus can be a major reason for project delays, cost and time overruns. 


\section{REFERENCES}

[1]. Adb.Majid, M.Z. Non-Excusable Delays in construction. Department of civil and Building Engineering, Laughborough University Loughborough, Leicestershire, UK (1997):Ph.D. Thesis.

[2]. Al-jibouri,S. H (2003):Monitoring system and their effectiveness for project cost control in constructions. International Journal of Project Management 21:145-154.

[3].Barnes, N.M. cost modeling - "An integrated approach to planning and cost control Engineering and process Economics". n.2,p 24-51,1977.

[4]. Benchmarking the Government Client Stage,1999,2 study.

[5]. Harris,F. and McCaffer. R.,2001. Modern Construction Management, 5th Edition Black well Science Ltd, Malden USA.

[6]. Mohd Faris Khamidi and Waris Ali Khan, "The cost monitoring of construction projects through earned value analysis", International conference on economics and finance research,Singapore,2011.

[7]. PMI Project Management Book Of Knowledge,(2004) 3rd Edition.

[8]. Zubair Ahmed Memon, Mudh. Zaimi Abd. Majidand Mushairry Mustaffar, 'A Systematic approach for monitoring and Evaluating the construction project progress' Journal-The Institution of Engineers, Malaysia (vol. 67,No. 3, September 2006).

\section{BIOGRAPHIES}

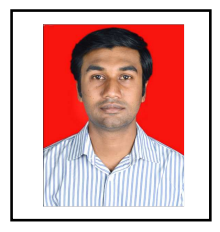

Shreyash R Raut doing research gradute persuing Master in Engineering Construction \& Management from Maharashtra Institute of Technology, Pune.

Prof.Dr.Sunil S.Pimplikar is currently working as Professor and Head of Civil Engineering Department at Maharashtra Institute

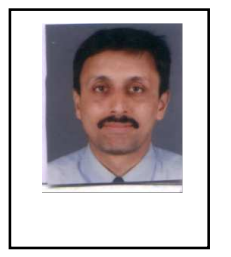
of Technology, Pune. He is the coordinator and faculty of the Post Graduate Program in Construction and Management. His research interests are Accident Studies, Total Quality Management, Contracts Management and Human Resource Management . 